\title{
Growth and Yield of Soybean (Glycine max L.) As Influenced By Boron Nutrition in a Vertisol
}

\author{
M.C. Chaithra* and N.S. Hebsur \\ University of Agricultural Sciences, Dharwad - 580 005, Karnataka, India \\ *Corresponding author
}

\begin{tabular}{|l|}
\hline K e y w o r d s \\
$\begin{array}{l}\text { Boron nutrition, } \\
\text { Solubor, Soybean, } \\
\text { Yield, Vertisol }\end{array}$ \\
\hline Article Info \\
$\begin{array}{l}\text { Accepted: } \\
26 \text { October } 2018 \\
\text { Available Online: } \\
\text { 10 November } 2018\end{array}$ \\
\hline
\end{tabular}

A B S T R A C T

A field experiment comprising recommended package of practices (RPP), RPP + soil (2.5 and $5.0 \mathrm{~kg} \mathrm{ha}^{-1}$ at $\left.10 \mathrm{DAS}\right)$, foliar (0.5 and $1.25 \%$ at 45 DAS) application of solubor and combination of both soil and foliar application was conducted during kharif 2017 at the MARS, University of Agricultural Sciences, Dharwad, Karnataka to study the boron nutrition effect on growth, nodulation, yield attributes and yield of soybean in boron deficient Vertisol. A Randomized Complete Block Design was used for the experiment with three replications. The results revealed that RPP along with soil (@ $\left.2.5 \mathrm{~kg} \mathrm{ha}^{-1}\right)+$ foliar (@0.5\%) application of solubor improved the growth and yield parameters significantly. However, soil application of solubor @ $5 \mathrm{~kg} \mathrm{ha}^{-1}$ recorded the highest number of effective nodules per plant (18.64).Seed yield $\left(2806 \mathrm{~kg} \mathrm{ha}^{-1}\right)$ response of soybean (16.97\% more yield than RPP) recorded with RPP + soil $\left(2.5 \mathrm{~kg} \mathrm{ha}^{-1}\right)$ and foliar $(0.5 \%)$ application of solubor was significant except that recorded with soil $\left(5 \mathrm{~kg} \mathrm{ha}^{-1}\right)$, soil $\left(5 \mathrm{~kg} \mathrm{ha}^{-1}\right)+$ foliar $(0.5 \%)$ and only foliar $(0.5 \%)$ application of solubor. However, slightly higher benefit cost ratio (2.97) was observed with foliar application of solubor (@ $0.5 \%)$.

\section{Introduction}

Soybean [Glycine $\max$ L.], a "Golden bean" and "Miracle crop" of $21^{\text {st }}$ century on account of its high nutritional values and economic importance. About 85 per cent of the world's soybean is processed annually in to soya meal and oil. Globally, United States, Brazil and Argentina contribute 80 per cent of the soybean supply. In India, soybean is cultivated in an area of $10.91 \mathrm{~m}$ ha with a production of $10.37 \mathrm{~m} \mathrm{t}$ and productivity of $951 \mathrm{~kg} \mathrm{ha}^{-1}$ (Anon., 2015). Madhya Pradesh being the largest producer and is known as "Soya state".
While in Karnataka the area under soybean is increasing year after year, during 2015-16 it is cultivated over an area of 2.56 lakh ha with a production and productivity of 1.85 lakh tonnes $779 \mathrm{~kg} \mathrm{ha}^{-1}$, respectively (Anon., 2015a).

However, the productivity is far lower than the average productivity of the country and world though the improved varieties are being cultivated. In spite of NPK fertilizers use, one of the reason for lower productivity could be ascribed to micronutrient deficiency especially boron. Both macro and micronutrients when 
applied in balanced proportions not only play an important role in crop growth and development, but also helps in improving quality and productivity of crops (Raun and Jhonson, 1999). Micronutrients viz., Fe, Mn, $\mathrm{Zn}, \mathrm{Cu}, \mathrm{B}, \mathrm{Mo}, \mathrm{Cl}$ and $\mathrm{Ni}$ are taken up by plants in very small amounts, but their role in crop production is as important as the macronutrients (Steven, 2000). Among the micronutrients the B deficiency in soil occurs next to $\mathrm{Zn}$. Nearly 33 per cent of soils in India are potentially deficient in boron (Maha, 2008). Boron deficiency is widespread in calcareous, low organic matter, acid and coarse textured soils.

Boron is directly involved in several physiological and bio-chemical processes during plant growth viz., protein synthesis, seed and cell wall formation, germination of pollen grains and growth of pollen tubes. It is important in plants to maintain the membrane integrity and cell wall development, which affects permeability, cell-division and its extension. It has been documented by researchers that the role of boron in seed production is so important that under moderate to severe boron deficiency, plants fail to produce functional flowers and may produce no seeds (Mozafar, 1993). The B deficiency symptoms first appear on the terminal buds or young leaves. The terminal buds become discoloured and die under conditions of acute boron deficiency. Internodes become shorter and give appearance of bushy or rosette, increased diameter of stem and petioles giving rise to the typical cracking of stem and fruit. The B requirement of the crops varies not only among crops it also varies with species. In general leguminous crops respond positively when the B is supplied through foliage right in the beginning of reproductive phase. Researchers have initiated trials to address the need of boron requirement in soybean in India, but the research work on Vertisol is limited. In the light of above, a field experiment is framed with an objective of assessing the boron nutrition effect on growth, nodulation and yield of soybean.

\section{Materials and Methods}

Field experiment was conducted during the rainy season (kharif -2017) at the MARS, University of Agricultural Sciences, Dharwad, Karnataka on Vertisol having pH 7.81 and free $\mathrm{CaCO}_{3} 5.01$ per cent. The soil was medium in organic carbon content $\left(5.85 \mathrm{~g} \mathrm{~kg}^{-1}\right)$ and available $\mathrm{P}_{2} \mathrm{O}_{5}\left(31.40 \mathrm{~kg} \mathrm{ha}^{-1}\right)$ and low in available $\mathrm{N}\left(167.60 \mathrm{~kg} \mathrm{ha}^{-1}\right)$ and hot water soluble B $\left(0.47 \mathrm{mg} \mathrm{kg}^{-1}\right)$. The Farm situated in Northern Transitional Zone (Zone 8) of Karnataka. The site was located at $15^{\circ} 29^{\prime} \mathrm{N}$ latitude and $74^{\circ} 59^{\prime}$ E longitude with an altitude of $678 \mathrm{~m}$ above mean sea level. The average rainfall in this area is approximately $72.05 \mathrm{~cm}$.

The treatments comprised two levels of soil application of solubor $\left(2.5\right.$ and $\left.5 \mathrm{~kg} \mathrm{ha}^{-1}\right)$ at 10 DAS, two levels of foliar application of solubor $(0.5$ and $1.25 \%)$ at 45 DAS and combination of soil and foliar application along with recommended package of practices with one control (RPP). The RPP for soybean crop includes : 40:80:25 kg N, $\mathrm{P}_{2} \mathrm{O}_{5}$ and $\mathrm{K}_{2} \mathrm{O}+$ FYM @ 6 tons $+\mathrm{ZnSO}_{4} .7 \mathrm{H}_{2} \mathrm{O} @ 12 \mathrm{~kg}+$ Gypsum @100 kg ha ${ }^{-1}$ and2per cent urea spray and seed treatment with Rhizobium $\left(1.25 \mathrm{~kg} \mathrm{ha}^{-1}\right)$. The experiment was laid out in randomized complete block design (total 9 treatments including control) with three replications.

Crop was raised by following recommended cultural practices and was harvested at maturity. Growth parameters viz., plant height, number of leaves per plant and number of branches per plant was recorded at different growth stages of crop. Total and effective nodules were counted by uprooting the plant at 50 DAS. While yield parameters (Number 
of pods plant ${ }^{-1}$, number of seeds $\operatorname{pod}^{-1}$, pod weight plant ${ }^{-1}$ and 100 seed weight) and yield were recorded at maturity. Oven dried (at 65 ${ }^{\circ} \mathrm{C}$ ) seed and haulm samples were powdered for chemical analysis. Nitrogen concentration was determined by Kjeldhal. $\mathrm{P}$ and $\mathrm{K}$ concentration in di-acid digest $\left(\mathrm{HNO}_{3}\right.$ and $\mathrm{HClO}_{4}$ in 9:4 ratio) was determined by vanado-molybdo phosphoric yellow colour method and flame photometer, respectively. The B content were estimated by azomethine$\mathrm{H}$ method after dry ashing using muffle furnace (Page et al 1982).

\section{Results and Discussion}

\section{Growth parameters}

Plant height and number of leaves and branches per plant

The plant height did not differ significantly at 30 DAS due to soil application of solubor. However, at 60 DAS and harvest plant height $(64.75$ and $68.01 \mathrm{~cm}$, respectively) was significantly higher with treatment $\left(\mathrm{T}_{6}\right)$ that received soil $\left(2.5 \mathrm{~kg} \mathrm{ha}^{-1}\right)+$ foliar $(0.5 \%)$ application of solubor except treatments $\mathrm{T}_{4}$ and $\mathrm{T}_{8}$ were on par with $\mathrm{T}_{6}$ (Table 1). Similar increase in number of leaves and number of branches per plant was observed with treatment $\left(\mathrm{T}_{6}\right)$ that received soil $\left(2.5 \mathrm{~kg} \mathrm{ha}^{-1}\right)+$ foliar $(0.5 \%)$ application of solubor. Both at 60 DAS and harvest treatment $\mathrm{T}_{9}$ (Soil @ $5 \mathrm{~kg}$ $\mathrm{ha}^{-1}+$ foliar@1.25\%) recorded lowest plant height (54.90 and $57.13 \mathrm{~cm}$, respectively) and number of branches per plant (4.00 and 4.27, respectively).

\section{Dry matter production per plant}

Dry matter production (24.26 $\mathrm{g} \mathrm{plant}^{-1}$ ) was significantly higher with $\mathrm{T}_{6}$ that received soil application of solubor @ $2.5 \mathrm{~kg} \mathrm{ha}^{-1}+$ foliar application of solubor @ 0.5 per cent. Treatments $\mathrm{T}_{4}$ and $\mathrm{T}_{8}$ were produced statistically on par dry matter with that of $\mathrm{T}_{6}$ (Table 2). The lowest dry matter production (17.5 $\mathrm{g} \mathrm{plant}^{-1}$ ) was with the treatment $\mathrm{T}_{9}$ that received soil (@5 kg ha ${ }^{-1}$ ) + foliar (@ 1.25\%) application of solubor.

\section{Number of nodules per plant at 50 DAS}

The data presented in table 2revealed that treatment $\left(T_{8}\right)$ that received soil application of solubor@ $5 \mathrm{~kg} \mathrm{ha}^{-1}+$ foliar application of solubor@0.5 per cent recorded the maximum number of total nodules (30.00). However, treatments $\mathrm{T}_{3}$ and $\mathrm{T}_{9}$ were on par with $\mathrm{T}_{8}$. The lowest number of total nodules (20.33) was observed in the $\mathrm{T}_{5}$ which received the foliar application of solubor @ 1.25 per cent at 50 DAS. Whereas, maximum number of effective nodules per plant was with treatment $\left(\mathrm{T}_{3}\right)$ which received soil application of solubor @ 5 $\mathrm{kg} \mathrm{ha}{ }^{-1}$ recorded the maximum number of effective nodules (18.64) at 50 DAS. However, treatments $\mathrm{T}_{8}$ and $\mathrm{T}_{9}$ were on par with $\mathrm{T}_{3}$. The minimum number of total and effective nodules was recorded in control.

\section{Yield parameters}

The number of pods (73.07) was significantly higher with treatment $\mathrm{T}_{4}$ that received foliar application of solubor (@0.5\%) over rest of the treatments except $\mathrm{T}_{3}, \mathrm{~T}_{6}$, and $\mathrm{T}_{8}$ treatments (Table 2). While number of seeds per pod (2.96) was significantly higher in the treatment $\mathrm{T}_{6}$ that received soil (@2.5 kg ha ${ }^{-1}$ ) + foliar (@0.5\%) application of solubor except that recorded with $\mathrm{T}_{2}, \mathrm{~T}_{3}, \mathrm{~T}_{4}, \mathrm{~T}_{5}$ and $\mathrm{T}_{8}$ treatments.

The lowest number of pods per plant (53.27) and number of seeds per pod (2.65) was with soil $\left(5 \mathrm{~kg} \mathrm{ha}^{-1}\right)+$ foliar $(1.25 \%)$ application of solubor $\left(\mathrm{T}_{9}\right)$. Application of solubor @ $2.5 \mathrm{~kg}$ $\mathrm{ha}^{-1}$ to soil + foliar application of solubor @ 0.5 per cent $\left(\mathrm{T}_{6}\right)$ produced significantly higher pod weight per plant (35. $34 \mathrm{~g} \mathrm{plant}^{-1}$ ). 
However, the effect of treatments $\mathrm{T}_{3}, \mathrm{~T}_{4}$ and $\mathrm{T}_{8}$ on pod weight per plant was statistically on par with $\mathrm{T}_{6}$. The data on 100 -seed weight did not differ significantly due to soil and foliar application of solubor.

\section{Seed and haulm yield}

Soil and foliar application of solubor significantly influenced the seed and haulm yield of soybean. The highest seed $(2,806$ and $\left.\mathrm{kg} \mathrm{ha}^{-1}\right)$ and haulm $\left(3,692 \mathrm{~kg} \mathrm{ha}^{-1}\right)$ yield with the treatment $\mathrm{T}_{6}$ that received soil $\left(2.5 \mathrm{~kg} \mathrm{ha}^{-1}\right)$ + foliar $(0.5 \%)$ application of solubor was significantly superior compared to other treatments except $T_{3}, T_{4}$ and $T_{8}$ treatments (Table 3).

The significantly lower seed $\left(2,091 \mathrm{~kg} \mathrm{ha}^{-1}\right)$ and haulm $\left(2,595 \mathrm{~kg} \mathrm{ha}^{-1}\right)$ yield was with $\mathrm{T}_{9}$ that received soil application of solubor @ 5 $\mathrm{kg} \mathrm{ha}^{-1}+$ foliar application of solubor @ 1.25 per cent.

\section{Nutrient uptake (N, P, K and B)}

Uptake of N, P, K and B by soybean varied significantly due to soil and foliar application of solubor. Treatment $\left(\mathrm{T}_{6}\right)$ that received soil application of solubor@ $2.5 \mathrm{~kg} \mathrm{ha}^{-1}+$ foliar application of solubor @ 0.5 per cent recorded the highest total uptake of N, P and K (195.53, 21.56 and $69.72 \mathrm{~kg} \mathrm{ha}^{-1}$, respectively) and it was significantly superior than all other treatments except $T_{3}, T_{4}$ and $T_{8}$ treatments.

However the lowest uptake of 125.84, 14.91, $50.83 \mathrm{~kg} \mathrm{ha}^{-1} \mathrm{~N}, \mathrm{P}$ and $\mathrm{K}$, respectively was with $\mathrm{T}_{9}$ that received soil application of solubor@5 kg ha-1 + foliar application of solubor@1.25 per cent (Table 3).The highest total boron uptake $\left(145.10 \mathrm{~g} \mathrm{ha}^{-1}\right)$ was recorded in the treatment $\left(\mathrm{T}_{7}\right)$ that received soil application of solubor@ $2.5 \mathrm{~kg} \mathrm{ha}^{-1}+$ foliar application of solubor @ 1.25 per cent and the treatments $T_{5}$ and $T_{9}$ were on par with
$\mathrm{T}_{7}$. The lowest uptake of boron by haulm, seed and total was recorded in the control (21.57, 38.32 and $59.88 \mathrm{~g} \mathrm{ha}^{-1}$, respectively).

\section{Economic analysis}

Economic analysis of different treatments involving application of solubor through soil as well as foliar revealed that maximum gross returns (₹99,522 $\mathrm{ha}^{-1}$ ) and net returns (₹65,317 $\mathrm{ha}^{-1}$ ) were obtained in the treatment $\mathrm{T}_{6}$ and $\mathrm{T}_{4}$, respectively (Table 4). Highest benefit cost ratio (2.97) was observed in treatment $\mathrm{T}_{4}$ that received foliar application of solubor@0.5 per cent followed by $\mathrm{T}_{6}$. Lowest benefit cost ratio (1.97) was observed in treatment $\mathrm{T}_{9}$ which received soil application of solubor @ $5 \mathrm{~kg} \mathrm{ha}^{-1}+$ foliar application of solubor@1.25 per cent.

\section{Growth parameters}

Boron application at optimum level is associated with increase in chlorophyll and in turn photosynthesis, cell division and cell elongation resulting in taller plants at all growth stages (Shahzad et al 2012). Thus soil application of solubor @ $2.5 \mathrm{~kg} \mathrm{ha}^{-1}+$ foliar application of solubor @ 0.5 per cent produced taller plants as compared to no boron application $\left(\mathrm{T}_{1}\right)$ and higher boron application rate $\left(\mathrm{T}_{9}\right)$. Eman and Haggan (2014) also found that foliar application of boron@800 $\mathrm{g} \mathrm{ha}^{-1}$ as borax increased soybean plant height at harvest by 5.02 per cent compared to control.

The increase in number of branches per plant might be ascribed to the role of boron in cell differentiation and development, translocation of photosynthates and growth regulator to various plant parts. The lower number of branches recorded in $\mathrm{T}_{9}$ treatment (even lower than no B treatment) indicate that higher dose is detrimental to crop growth soybean is a medium boron requiring crop. 
Table.1 Effect of soil and foliar application of solubor on plant height, number of branches and nodules of soybean at different growth stages

\begin{tabular}{|c|c|c|c|c|c|c|c|c|}
\hline \multirow[t]{2}{*}{ Treatments } & \multicolumn{3}{|c|}{ Plant height (cm) } & \multicolumn{3}{|c|}{ Number of branches } & \multicolumn{2}{|c|}{ Number of leaves } \\
\hline & 30 DAS & 60 DAS & Harvest & 30 DAS & 60 DAS & Harvest & 30 DAS & 60 DAS \\
\hline$T_{1}$ & $21.69^{\mathrm{a}}$ & $55.55^{b}$ & $58.09^{b c}$ & $1.40^{\mathrm{a}}$ & $4.67^{\mathrm{cd}}$ & $4.87^{\mathrm{cd}}$ & $5.73^{\mathrm{a}}$ & $18.72^{\mathrm{cd}}$ \\
\hline $\mathbf{T}_{2}$ & $23.14^{\mathrm{a}}$ & $56.69^{b}$ & $59.29^{b c}$ & $1.40^{\mathrm{a}}$ & $4.93^{\mathrm{bc}}$ & $5.27^{\mathrm{bc}}$ & $6.13^{a}$ & $19.55^{b-d}$ \\
\hline$T_{3}$ & $23.51^{\mathrm{a}}$ & $56.23^{b}$ & $58.89^{b c}$ & $1.47^{\mathrm{a}}$ & $5.60^{\mathrm{ab}}$ & $5.80^{\mathrm{ab}}$ & $6.27^{\mathrm{a}}$ & $19.56^{\mathrm{b}-\mathrm{d}}$ \\
\hline $\mathbf{T}_{4}$ & $21.89^{\mathrm{a}}$ & $60.35^{\mathrm{ab}}$ & $63.99^{a b}$ & $1.53^{\mathrm{a}}$ & $5.53^{\mathrm{ab}}$ & $5.80^{\mathrm{ab}}$ & $5.67^{\mathrm{a}}$ & $20.64^{\mathrm{a}-\mathrm{c}}$ \\
\hline $\mathbf{T}_{5}$ & $22.11^{\mathrm{a}}$ & $57.51^{b}$ & $59.71^{b c}$ & $1.47^{\mathrm{a}}$ & $5.13^{a-c}$ & $5.40^{\mathrm{a}-\mathrm{c}}$ & $5.93^{\mathrm{a}}$ & $19.80^{\mathrm{a}-\mathrm{d}}$ \\
\hline$T_{6}$ & $21.85^{\mathrm{a}}$ & $64.75^{\mathrm{a}}$ & $68.01^{\mathrm{a}}$ & $1.53^{\mathrm{a}}$ & $5.73^{\mathrm{a}}$ & $6.00^{\mathrm{a}}$ & $6.00^{\mathrm{a}}$ & $22.47^{\mathrm{a}}$ \\
\hline $\mathbf{T}_{7}$ & $21.86^{\mathrm{a}}$ & $55.82^{b}$ & $58.50^{b c}$ & $1.47^{\mathrm{a}}$ & $4.60^{\mathrm{cd}}$ & $4.80^{\mathrm{cd}}$ & $6.13^{\mathrm{a}}$ & $19.72^{\mathrm{a}-\mathrm{d}}$ \\
\hline$T_{8}$ & $22.41^{\mathrm{a}}$ & $60.47^{\mathrm{ab}}$ & $63.87^{\mathrm{ab}}$ & $1.53^{\mathrm{a}}$ & $5.40^{\mathrm{ab}}$ & $5.67^{\mathrm{ab}}$ & $6.27^{\mathrm{a}}$ & $21.84^{\mathrm{ab}}$ \\
\hline$T_{9}$ & $21.93^{\mathrm{a}}$ & $54.90^{\mathrm{b}}$ & $57.13^{c}$ & $1.47^{\mathrm{a}}$ & $4.00^{d}$ & $4.27^{\mathrm{d}}$ & $6.33^{\mathrm{a}}$ & $17.07^{\mathrm{d}}$ \\
\hline LSD & NS & 5.45 & 5.33 & NS & 0.64 & 0.59 & NS & 2.55 \\
\hline
\end{tabular}

Table.2 Effect of soil and foliar application of solubor on number leaves, dry matter production and yield components of soybean

\begin{tabular}{|c|c|c|c|c|c|c|c|}
\hline Treatments & $\begin{array}{l}\text { Dry matter } \\
\left.\text { production }^{(\mathrm{g} \text { plant }}{ }^{-1}\right)\end{array}$ & $\begin{array}{c}\text { Total } \\
\text { nodules }\end{array}$ & $\begin{array}{c}\text { Effective } \\
\text { nodules }\end{array}$ & $\begin{array}{l}\text { Number of } \\
\text { pods plant }^{-1}\end{array}$ & $\begin{array}{c}\text { Number } \\
\text { of seeds } \\
\text { pod }^{-1}\end{array}$ & $\begin{array}{l}\text { Pod weight } \\
\text { plant }^{-1}\end{array}$ & $\begin{array}{l}\text { Test weight } \\
\text { (100 seeds) }\end{array}$ \\
\hline $\mathbf{T}_{1}$ & $19.54^{\mathrm{e}}$ & $20.50^{c}$ & $11.77^{\mathrm{d}}$ & $64.93^{b c}$ & $2.65^{\mathrm{c}}$ & $30.21^{\mathrm{c}}$ & $11.94^{\mathrm{a}}$ \\
\hline $\mathbf{T}_{2}$ & $21.29^{d}$ & $25.17^{b}$ & $16.62^{\mathrm{ab}}$ & $65.53^{b c}$ & $2.86^{a b}$ & $32.10^{\mathrm{bc}}$ & $11.91^{\mathrm{a}}$ \\
\hline $\mathbf{T}_{3}$ & $21.78^{b-d}$ & $29.67^{a}$ & $18.64^{\mathrm{a}}$ & $70.00^{a b}$ & $2.92^{\mathrm{a}}$ & $32.58^{\mathrm{a}-\mathrm{c}}$ & $12.01^{\mathrm{a}}$ \\
\hline$T_{4}$ & $23.65^{\mathrm{a}-\mathrm{c}}$ & $22.50^{\mathrm{c}}$ & $13.67^{\mathrm{cd}}$ & $73.07^{\mathrm{a}}$ & $2.91^{\mathrm{a}}$ & $33.30^{\mathrm{a}-\mathrm{c}}$ & $11.93^{\mathrm{a}}$ \\
\hline $\mathbf{T}_{5}$ & $19.33^{\mathrm{e}}$ & $20.33^{c}$ & $13.28^{\mathrm{d}}$ & $62.93^{c}$ & $2.83^{a-c}$ & $30.42^{c}$ & $11.87^{\mathrm{a}}$ \\
\hline$T_{6}$ & $24.26^{\mathrm{a}}$ & $26.33^{b}$ & $15.36^{b c}$ & $72.93^{\mathrm{a}}$ & $2.96^{\mathrm{a}}$ & $35.34^{\mathrm{a}}$ & $12.23^{\mathrm{a}}$ \\
\hline $\mathbf{T}_{7}$ & $19.63^{\mathrm{de}}$ & $26.83^{b}$ & $16.73^{a b}$ & $62.07^{\mathrm{c}}$ & $2.69^{b c}$ & $30.45^{c}$ & $11.93^{\mathrm{a}}$ \\
\hline $\mathbf{T}_{8}$ & $23.79^{a b}$ & $30.00^{\mathrm{a}}$ & $17.83^{\mathrm{a}}$ & $72.07^{\mathrm{a}}$ & $2.95^{\mathrm{a}}$ & $34.68^{a b}$ & $12.01^{\mathrm{a}}$ \\
\hline$T_{9}$ & $17.50^{\mathrm{e}}$ & $29.50^{\mathrm{a}}$ & $18.54^{\mathrm{a}}$ & $53.27^{d}$ & $2.68^{b c}$ & $26.47^{\mathrm{d}}$ & $11.82^{\mathrm{a}}$ \\
\hline LSD & 2.21 & 2.59 & 1.89 & 5.02 & 0.18 & 2.87 & NS \\
\hline
\end{tabular}

Table.3 Effect of soil and foliar application of solubor on seed, haulm yield and uptake nutrients of soybean

\begin{tabular}{|c|c|c|c|c|c|c|}
\hline \multirow{2}{*}{$\begin{array}{c}\text { Treatmen } \\
\text { ts }\end{array}$} & \multirow{2}{*}{$\begin{array}{l}\text { Seed yield } \\
\left(\mathrm{kg} \mathrm{ha}^{-1}\right)\end{array}$} & \multirow{2}{*}{$\begin{array}{l}\text { Haulm yield } \\
\qquad\left(\mathrm{kg} \mathrm{ha}^{-1}\right)\end{array}$} & \multicolumn{3}{|c|}{ Uptake $\left(\mathrm{kg} \mathrm{ha}^{-1}\right)$} & \multirow{2}{*}{$\begin{array}{c}\text { Uptake }\left(\mathrm{g} \mathrm{ha}^{-1}\right) \\
\text { B }\end{array}$} \\
\hline & & & $\mathbf{N}$ & $\mathbf{P}$ & K & \\
\hline $\mathrm{T}_{1}$ & $2,399^{b-d}$ & $2,671^{b}$ & $147.73^{\mathrm{cd}}$ & $17.01^{\mathrm{cd}}$ & $55.75^{b}$ & $59.88^{\mathrm{e}}$ \\
\hline$T_{2}$ & $2,417^{b-d}$ & $2,817^{b}$ & $153.71^{b c}$ & $17.54^{\mathrm{bc}}$ & $57.28^{b}$ & $71.66^{\mathrm{de}}$ \\
\hline $\mathbf{T}_{3}$ & $2,657^{\mathrm{a}-\mathrm{c}}$ & $3,177^{\text {ab }}$ & $176.95^{a b}$ & $19.55^{\mathrm{ab}}$ & $63.56^{\mathrm{a}}$ & $85.42^{\mathrm{d}}$ \\
\hline$T_{4}$ & $2,784^{\mathrm{a}}$ & $3,552^{\mathrm{a}}$ & $188.42^{a}$ & $21.19^{\mathrm{a}}$ & $68.32^{\mathrm{a}}$ & $121.52^{c}$ \\
\hline$T_{5}$ & $2,260^{d}$ & $2,917^{\mathrm{b}}$ & $141.86^{\mathrm{cd}}$ & $16.65^{\mathrm{cd}}$ & $55.75^{b}$ & $137.43^{\mathrm{ab}}$ \\
\hline$T_{6}$ & $2,806^{\mathrm{a}}$ & $3,692^{\mathrm{a}}$ & $195.53^{a}$ & $21.56^{\mathrm{a}}$ & $69.72^{a}$ & $125.38^{\mathrm{bc}}$ \\
\hline $\mathbf{T}_{7}$ & $2,296^{\text {cd }}$ & $2,962^{b}$ & $146.29^{\mathrm{cd}}$ & $16.85^{\mathrm{cd}}$ & $56.54^{b}$ & $145.10^{\mathrm{a}}$ \\
\hline$T_{8}$ & $2,752^{a b}$ & $3,621^{\mathrm{a}}$ & $190.66^{a}$ & $21.00^{\mathrm{a}}$ & $68.55^{\mathrm{a}}$ & $129.44^{\mathrm{bc}}$ \\
\hline$T_{9}$ & $2,091^{d}$ & $2,595^{b}$ & $125.84^{d}$ & $14.91^{\mathrm{d}}$ & $50.83^{b}$ & $135.60^{\mathrm{a}-\mathrm{c}}$ \\
\hline LSD & 333.99 & 545.58 & 24.12 & 2.05 & 5.94 & 14.15 \\
\hline
\end{tabular}


Table.4 Economics of soybean as influenced by soil and foliar application of solubor

\begin{tabular}{|c|c|c|c|c|}
\hline $\begin{array}{c}\text { Treatment } \\
\text { details }\end{array}$ & Cost of cultivation & Gross returns & Net returns & Benefit cost ratio \\
\hline $\mathbf{T}_{\mathbf{1}}$ & 31,501 & 83,613 & 52,112 & 2.65 \\
\hline $\mathbf{T}_{\mathbf{2}}$ & 32,675 & 85,244 & 52,569 & 2.61 \\
\hline $\mathbf{T}_{\mathbf{3}}$ & 33,612 & 94,465 & 60,853 & 2.81 \\
\hline $\mathbf{T}_{\mathbf{4}}$ & 33,143 & 98,460 & 65,317 & 2.97 \\
\hline $\mathbf{T}_{\mathbf{5}}$ & 35,252 & 80,145 & 44,893 & 2.27 \\
\hline $\mathbf{T}_{\mathbf{6}}$ & 34,317 & 99,522 & 65,205 & 2.90 \\
\hline $\mathbf{T}_{\mathbf{7}}$ & 36,426 & 81,377 & 44,951 & 2.23 \\
\hline $\mathbf{T}_{\mathbf{8}}$ & 35,254 & 98,165 & 62,911 & 2.78 \\
\hline $\mathbf{T}_{\mathbf{9}}$ & 37,363 & 73,656 & 36,293 & 1.97 \\
\hline
\end{tabular}

$\mathrm{T}_{1:}$ Control, $\mathrm{T}_{2}$ : Soil application of solubor @ $2.5 \mathrm{~kg} \mathrm{ha}^{-1}, \mathrm{~T}_{3}$ : Soil application of solubor @ $5.0 \mathrm{~kg} \mathrm{ha}^{-1}, \mathrm{~T}_{4}$ : Foliar application of solubor@ $0.5 \%, \mathrm{~T}_{5}$ : Foliar application of solubor @ $1.25 \%, \mathrm{~T}_{6}$ : Soil application of solubor @ $2.5 \mathrm{~kg}$ $\mathrm{ha}^{-1}+$ Foliar application of solubor @ $0.5 \%, \mathrm{~T}_{7}$ : Soil application of solubor @ $2.5 \mathrm{~kg} \mathrm{ha}^{-1}+$ Foliar application of solubor@1.25\%, $\mathrm{T}_{8:}$ Soil application of solubor @ $5.0 \mathrm{~kg} \mathrm{ha}^{-1}+$ Foliar application of solubor @ 0.5\%, $\mathrm{T}_{9}$ : Soil application of solubor@ $5.0 \mathrm{~kg} \mathrm{ha}^{-1}+$ Foliar application of solubor @ $1.25 \%$.

Foliar application of solubor at reproductive phase significantly increased number of leaves whereas soil application of solubor found nonsignificant. The increase in number of leaves could be attributed to enhanced metabolic physiological activity leading to improved translocation of photosynthates. Similar results were reported by Kulkarni et al., (2002) and Ahmed et al., (2008) in sunflower and cotton crops.

The increase in nodule number could be due to enhancement of the Rhizobium activity with the boron nutrition. The positive effect of boron on root nodulation in soybean was reported by Rahman et al., (1999). The inoculated bacteria formed healthy and pink nodules on roots of soybean in the presence of boron.

Adequate or proper or optimum and timely supply of nutrients (N, P, K, S, Zn and B) is associated with vigorous vegetative growth which in turn resulted in increased photosynthetic surface, enhancing the carbohydrate metabolism thus contributing to higher dry matter accumulation. According to Syed et al., (2013) application of borax @ $20 \mathrm{~kg}$ $\mathrm{ha}^{-1}$ recorded highest dry matter yield $(1705 \mathrm{~kg}$ $\mathrm{ha}^{-1}$ ) in soybean. But, application of higher quantity of boron decreased the dry matter yield due to toxic effects. Consequently, the lowest dry matter production (17.5 $\left.\mathrm{g} \mathrm{plant}^{-1}\right)$ was recorded in the treatment $\mathrm{T}_{9}$ that received maximum boron through soil $\left(5 \mathrm{~kg} \mathrm{ha}^{-1}\right)+$ foliar $(1.25 \%)$ application of solubor. The beneficial influence of applied B may on growth parameters may be due to increased availability and absorption of $\mathrm{B}$ for the metabolic and physiological activity of growing plants

\section{Yield parameters}

Increased photosynthetic efficiency, improved nutrient uptake and translocation of nutrients enhanced the dry matter production which has profound influence on yield parameters. Thus application of boron at right dose and at right time might have influenced all the yield parameters such as number of pods plant ${ }^{-1}$, number of seeds $\operatorname{pod}^{-1}$, pod weight plant ${ }^{-1}$ and 100 seed weight through it role in metabolic activity and also pollination. It has been reported by several workers that application of $\mathrm{B}$ at the beginning of reproductive stages has improved the seed setting by preventing seed abortion in soybean. Similar findings were also documented by Mary and Dale et al., (1990), Deviand Singh (2012) and Layek et al., (2014) in soybean crop 


\section{Seed and haulm yield}

Final yield is an expression of physiological and metabolic activity of plant under given nutrient management practices under favourable climatic conditions. The above ground yield in soybean (seed and haulm) depends on response exhibited by growth and yield attributing factors as influenced by the supply of optimum amount of $\mathrm{N}, \mathrm{P}, \mathrm{K}, \mathrm{S}, \mathrm{Zn}$ and $\mathrm{B}$. The seed yield is directly and significantly related to number of pods, pod weight per plant, number of seeds per plant and test weight. In the present investigation all the growth and yield parameters were improved significantly with the soil @ $2.5 \mathrm{~kg} \mathrm{ha}^{-1}$ and foliar @ 0.5 per cent solubor application consequently the seed and haulm yield was higher in the same treatment. Higher dose of solubor i.e., soil @ $5 \mathrm{~kg} \mathrm{ha}^{-1}$ and foliar@1.25 per cent had adverse effect on growth and yield parameters and thus recorded lower yield than other boron treatments and no boron application. Lower level of soil application of solubor $\left(2.5 \mathrm{~kg} \mathrm{ha}^{-1}\right)$ might be sufficient to meet the $\mathrm{B}$ requirement during the early growth of crop and foliar spray of soluborat the end of vegetative phase (at 45 DAS) has taken care of B requirement at later part of growing period resulting in higher seed yield than application of solubor at higher dose.

\section{Nutrient uptake (N, P, K and B)}

Treatment $\left(\mathrm{T}_{6}\right)$ that received soil $\left(2.5 \mathrm{~kg} \mathrm{ha}^{-1}\right)+$ foliar $(0.5 \%)$ application of solubor recorded significantly higher total uptake (seed + haulm) of nitrogen, phosphorous and potassium $\left(195.53,21.56\right.$ and $69.72 \mathrm{~kg} \mathrm{ha}^{-1} \mathrm{~N}, \mathrm{P}$ and $\mathrm{K}$, respectively) at harvest. Higher uptake of nutrients by soybean could be due to higher dry matter, seed and haulm yields. The increased uptake of $\mathrm{N}, \mathrm{P}$ and $\mathrm{K}$ by soybean with boron application might be due to its synergetic effect. Synergistic effects of boron with N, P, K and sulphur were reported by Tandon (1989) and Syed et al., (2013). Longkumer et al., (2017) also reported that the total nutrient uptake of $\mathrm{N}$, $\mathrm{P}, \mathrm{K}, \mathrm{S}$ and $\mathrm{B}$ by soybean increased with increasing levels of $\mathrm{S}$ and $\mathrm{B}$ application individually. Treatment $\mathrm{T}_{7}$ that received soil application of solubor $\left(2.5 \mathrm{~kg} \mathrm{ha}^{-1}\right)+$ foliar $(1.25 \%)$ application of solubor recorded the highest total uptake of boron (145.10 $\left.\mathrm{g} \mathrm{ha}^{-1}\right)$. However, treatments $T_{5}$ and $T_{9}$ were on par with $\mathrm{T}_{7}$. It might be due to higher availability of boron which was supplied through soil as well as foliar. The lowest total boron uptake (59.88 $\mathrm{g}$ $\mathrm{ha}^{-1}$ ) was noticed in the control. Devi and Singh (2012) also found that application of boron significantly influenced the $\mathrm{B}$ uptake by soybean in that the highest boron uptake of 135 $\mathrm{g} \mathrm{ha}^{-1}$ was recorded with the application of 1.5 $\mathrm{kg}$ boron ha $\mathrm{a}^{-1}$ and the lowest boron uptake (44 $\mathrm{g}$ $\mathrm{ha}^{-1}$ ) was in control.

\section{Economic analysis}

Maximum gross returns ( $₹ 99,522 \mathrm{ha}^{-1}$ ) was obtained in the treatment $\mathrm{T}_{6}$ that received soil $\left(2.5 \mathrm{~kg} \mathrm{ha}^{-1}\right)+$ foliar $(0.5 \%)$ application of solubor and highest net returns (₹65,317ha ${ }^{-1}$ ) was obtained in the treatment $T_{4}$ that received foliar application of solubor @ 1.25 per cent. However, highest benefit cost ratio (2.97) was observed in treatment $T_{4}$. It could be attributed to increase in seed and haulm yield as a result of better utilization of both applied and native nutrients and also quantity of boron needed for foliar application is less as compared to soil application.

Based on the response of soybean in terms of growth, yield, quality parameters, uptake of nutrients, gross returns, net returns and benefit cost ratio, soil application of solubor @ $2.5 \mathrm{~kg}$ $\mathrm{ha}^{-1}+$ foliar application of solubor @ 0.5 per cent was found optimum and beneficial to soybean in a Vertisol. However, the treatment $\mathrm{T}_{4}$ which received foliar application of solubor @ 0.5 per centwas equally effective as $\mathrm{T}_{6}$.

\section{References}

Ahmed, N., Abid, M. and Ahmad, F., 2008, Boron toxicity in irrigated cotton (Gossypium hirsutum L.). Pakistan J. Botany, 40: 2443-2445

Anonymous, 2015, www.sopaorg.

Anonymous, 2015a, www.raitamitra.kar.nic. in. 
Devi, K. N. and Singh, L. N. K., 2012, Influence of sulphur and boron fertilization on yield, quality, nutrient uptake and economics of soybean (Glycine max) under upland conditions. $J$. Agric. Sci., 4(4): 1-10.

Eman, E. A. L. and Haggan, E. M. A., 2014, Effect of micronutrients foliar application on yield and quality traits of soybean cultivars. Int. J. Agric. Crop Sci., 7(11): 908-914.

Kulkarni, S. S. Babu, R. and Pujari, B., 2002, Growth, yield and yield parameters of sunflower as influenced by organic manures, biofertilizers and micronutrients under irrigation. Karnataka J. Agric. Sci., 15: 253-255.

Layek, J., Shivakumar, B. G., Rana, D. S., Gangaiah, B., Lakshman, K. and Paramanik, B., 2014, Growth, nodulation, physiological indices and yield of soybean as influenced by sulphur and boron nutrition. Int. J. Life Sci., 9 (4): 1389-1393.

Longkumer, L. T., Singh, A. K., Jamir, Z. and Manoj, K., 2017, Effect of sulfur and boron nutrition on yield and quality of soybean (Glycine max L.) grown in an acid soil. Commun. Soil Sci. Plant Anal., 48(4): 405-411.

Maha V. S., 2008, Micronutrient Deficiencies in Global Crop Production. Springer Science+ Business media B. V, p. 93.

Mary, K. S. and Dale G. B., 1990, Foliar boron applications increase the final number of branches and pods on branches of fieldgrown soybeans. Plant Physiol., 92: 602607.
Mozafar, A., 1993, Role of Boron in Seed Production. In: (Ed. Gupta, U. C.) Boron and its Role in Crop Production. Boca Raton, FL: CRC Press, pp. 187-208.

Page, A. L., Miller, R. H. and Keeney, D. R., 1982, Method of soil analysis Part-II. Soil Sci. Am., Madison, Wisconsin, USA.

Rahman, M. H. H., Arima, Y., Watanabe, K. and Sekimoto, H., 1999, Adequate range of boron nutrition is more restricted for root nodule development than for plant growth in young soybean (Glycine max L.) plant. Soil Sci. Plant Nutrition (Japan). 45(2): 287-296.

Raun, W. R. and Jhonson, G. V., 1999, Improving nitrogen use efficiency for cereal production. Agron. J., 91: 357-363.

Shahzad, K., Muhammad, A. S., Iqbal, M., Arif, M., 2012, Response of maize (Zea mays L.) genotypes to soil and foliar application of boron. Asian J. Pharm. Biol. Res., 2(1): 65-72.

Steven, C. H., 2000, Soil fertility basics, soil science extension, North Carolina state University. Certified crop advisor training, p. 75 .

Syed, J. J., Ismail, S., Kosare, C. S., 2013, Interaction effect of sulphur and boron on yield, nutrient uptake and quality of soybean grown on Vertisol. Asian J. Soil Sci., 80: 275-278.

Tandon, H. L. S., 1989, Secondary and Micronutrient Recommendations for Soil and Crops- A Guide book, Fertilizers Development and Consultation Organization, New Delhi.

\section{How to cite this article:}

Chaithra, M.C. and Hebsur, N.S. 2018. Growth and Yield of Soybean (Glycine max L.) as Influenced by Boron Nutrition in a Vertisol. Int.J.Curr.Microbiol.App.Sci. 7(11): 3293-3300. doi: https://doi.org/10.20546/ijcmas.2018.711.380 